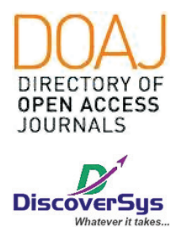

Published by DiscoverSys

\section{Hipertensi sebagai prediktor kejadian kardiovaskular mayor pada pasien infark miokard akut pada tahun 2018 di RSUP Sanglah Denpasar, Bali-Indonesia}

\author{
A A Ayu Kaivalya Kirthi, ${ }^{1 *}$ A. A. Ayu Dwi Adelia Yasmin, ${ }^{2}$ \\ I Made Junior Rina Artha, ${ }^{2}$ Agha Bhargah ${ }^{3}$
}

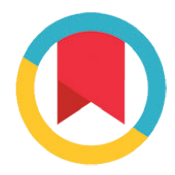

CrossMark

\begin{abstract}
Introduction: Acute Myocardial Infarction (AMI) is a leading cause of morbidity and mortality in developed countries, as well as emerged as a very important health problem in developing countries. Despite of management and treatment of AMI strategies has been evolving. Complications due to AMI cause high morbidity and mortality. To minimalize complications in AMI patients need some risk stratification. Risk stratification have been made based on AMI pathophysiology. Hypertension is a factor that directly influences the development of atherosclerosis through mechanical stress.

Method: This study was a retrospective cohort observational study that enrolled 70 patients with $\mathrm{AMI}$ as the subject of research by consecutive sampling from January 2018 - September 2018. Data

retrieval is done by taking data from medical records of patients in the Sanglah General Hospital. Outcome observed was in-hospital MACE (cardiovascular death, cardiogenic shock, heart failure, and malignant arrhythmias).

Result: In this study, it was found that hypertension is a predictor of major cardiovascular events by almost 5-fold $(\mathrm{HR}=5,02,95 \% \mathrm{Cl}=$ $1,32-19,20, p=<0.018$ in patients with AMI that were treated at Sanglah General Hospital.

Conclusion: The conclusion of this study is hypertension is a predictor of major cardiovascular events in patients with AMI on admission to hospital. The results of this study are expected to be used as baseline data for subsequent larger studies.
\end{abstract}

1Program Studi Pendidikan Dokter, Fakultas Kedokteran Universitas Udayana

${ }^{2}$ Departemen/KSM Kardiologi dan Kedokteran Vaskuler RSUP Sanglah Denpasar

${ }^{3}$ Fakultas Kedokteran Universitas Udayana, Bali-Indonesia

*Correspondence to: A A Ayu Kaivalya Kirthi, Program Studi Pendidikan Dokter, Fakultas Kedokteran Universitas Udayana kaivalyakirthi16@gmail.com

Diterima: $14-03-2019$

Disetujui: 11-04-2019

Diterbitkan: 01-12-2019
Keywords: hypertension, acute myocardial infarction, major adverse cardiovascular events.

Cite This Article: Kirthi, A.A.A.K., Yasmin, A.A.A.D.A., Artha, I.M.J.R., Bhargah, A. 2019. Hipertensi sebagai prediktor kejadian kardiovaskular mayor pada pasien infark miokard akut pada tahun 2018 di RSUP Sanglah Denpasar, Bali-Indonesia. Intisari Sains Medis 10(3): 530-536. DOl: 10.15562/ism.v10i3.443

\section{ABSTRAK}

Latar Belakang: Infark Miokard Akut (IMA) merupakan penyebab utama morbiditas dan mortalitas yang utama di negara maju serta menjadi masalah kesehatan yang sangat penting di negara berkembang. Meskipun pengobatan dan strategi tatalaksana pasien IMA sudah banyak mengalami perkembangan. Komplikasi akibat IMA merupakan penyebab tingginya angka mortalitas pasien IMA. Untuk minimalisir komplikasi pada pasien IMA diperlukan stratifikasi risiko pasien IMA. Hipertensi merupakan faktor yang langsung berpengaruh dalam perkembangan aterosklerosis dengan melalui stress mekanis. Metode: Penelitian ini merupakan studi observasional kohort retrospektif yang mengikutsertakan 70 pasien IMA sebagai subjek penelitian berdasarkan consecutive sampling selama periode Januari 2018 - September 2018. Pengambilan data dilakukan dengan mengambil data dari catatan medis pasien di RSUP Sanglah. Luaran yang diamati selama pasien dirawat adalah kejadian kardiovaskular mayor (kematian kardiovaskular, syok kardiogenik, gagal jantung, dan aritmia lethal).

Hasil: Pada penelitian ini didapatkan bahwa hipertensi merupakan prediktor kejadian kardiovaskular mayor sebesar hampir 5 kali lipat ( $H R=5,02,95 \% \mathrm{Cl}=1,32-19,20$, nilai $\mathrm{p}=<0,018$ pada pasien IMA yang dirawat di RSUP Sanglah.

Simpulan: Kesimpulan dari penelitian ini adalah hipertensi merupakan prediktor kejadian kardiovaskular mayor pada pasien IMA saat perawatan di rumah sakit. Hasil penelitian ini diharapkan dapat digunakan sebagai data dasar untuk penelitian berikutnya yang lebih besar.
Kata Kunci: Hipertensi, infark miokard akut, kejadian kardiovaskular mayor.

Cite Pasal Ini: Kirthi, A.A.A.K., Yasmin, A.A.A.D.A., Artha, I.M.J.R., Bhargah, A. 2019. Hipertensi sebagai prediktor kejadian kardiovaskular mayor pada pasien infark miokard akut pada tahun 2018 di RSUP Sanglah Denpasar, Bali-Indonesia. Intisari Sains Medis 10(3): 530-536. DOl: 10.15562/ism.v10i3.443 


\section{PENDAHULUAN}

Secara global World Health Organization (WHO) memperkirakan penyakit tidak menular menyebabkan sekitar $60 \%$ kematian dan $43 \%$ kesakitan di seluruh dunia. Salah satu penyakit yang termasuk dalam kelompok penyakit tidak menular tersebut yaitu hipertensi.

Menurut American Heart Association (AHA), penduduk Amerika yang berusia diatas 20 tahun menderita hipertensi telah mencapai angka hingga 74,5 juta jiwa, namun hampir sekitar 90-95\% kasus tidak diketahui penyebabnya. Hipertensi merupakan faktor risiko utama penyakit jantung koroner dan stroke iskemik serta hemoragik. ${ }^{1}$

Penyakit jantung koroner (PJK) yang juga disebut dengan penyakit arteri koroner merupakan penyakit kardiovaskular dengan angka kematian yang tinggi. Pada tahun 2014 penyakit jantung koroner menjadi penyebab 1 dari 7 kematian di Amerika Serikat. Terdapat 264.593 orang Amerika meninggal akibat PJK. Setiap tahunnya, diperkirakan sekitar 695.000 orang Amerika mendapat serangan jantung koroner (didefinisikan sebagai kejadian rawat inap pertama akibat dari infark miokard akut (IMA) atau kematian akibat penyakit jantung koroner) dan sekitar 325.000 orang mengalami serangan berulang. ${ }^{1}$

IMA merupakan keadaan kegawat daruratan jantung dimana terjadi kematian sel miokardium akibat dari tersumbatnya secara total pembuluh darah koroner. IMA merupakan bagian dari sindrom koroner akut.

Tingginya morbiditas dan mortalitas dari pasien IMA disebabkan oleh komplikasi yang disebabkan dari penyakit ini. Beberapa komplikasinya berupa komplikasi iskemik, mekanik, gangguan irama jantung, emboli dan kematian. Dengan kejadian kardiovaskular mayor merupakan komplikasi IMA yang berhubungan secara langsung dengan tingkat harapan hidup pasien. ${ }^{2}$

Gagal jantung dengan penurunan kontraktilitas ventrikel kiri atau kanan adalah komplikasi mekanik IMA yang penting. Pada gagal jantung kanan, pengisian ventrikel kiri akan terganggu yang menyebabkan penurunan curah jantung secara mendadak. Mortalitas gagal jantung pasca IMA mencapai 57\%. ${ }^{3}$ Penurunan kontraktilitas tersebut dapat menyebabkan syok kardiogenik. Syok kardiogenik merupakan prediktor utama kematian di rumah sakit, dan didapatkan prevalensi syok kardiogenik yang serupa pada kelompok pasien NSTEMI dan STEMI.

Komplikasi IMA yang juga berhubungan dengan survival rate adalah berbagai aritmia maligna yang dapat menyebabkan gangguan hemodinamik pada pasien, contohnya takiaritmia supraventrikular dan takiaritmia ventrikular yang menetap, serta blok atrioventrikular derajat tinggi. Komplikasi iskemik yang termasuk dalam kejadian kardiovaskular mayor adalah angina pasca infark, yang mengambarkan adanya suatu perluasan infark, infark berulang pada teritori arteri koroner yang lain, atau reoklusi pada arteri koroner yang berhubungan dengan infark. ${ }^{2}$

Sistem stratifikasi IMA yang banyak digunakan saat ini adalah sistem skoring dengan skor The Thrombolysis in Myocardial Infarction (TIMI) dan skor GRACE. Perhitungan skoring risiko dengan menggunakan skor TIMI dan skor GRACE merupakan upaya stratifikasi risiko non-invasif dengan memadukan keadaan klinis, hemodinamik, elektrokardiografi, angiografi, dan nilai troponin. ${ }^{3,4}$ Pemeriksaan yang lebih sederhana untuk menentukan stratifikasi risiko pasien IMA sangat dibutuhkan dalam penentuan strategi tatalaksana dan menentukan prognosis.

Keadaan hipertensi menyebabkan hipertrofi jantung yang merupakan faktor risiko independen untuk infark miokard dan dapat menyebabkan kejadian kardiovaskular mayor. Hipertrofi ventrikel kiri untuk meningkatkan kekuatan pompa. Kondisi hipertrofi mengakibatkan kebutuhan oksigen miokard meningkat. Bila proses asteroklorosis terjadi, maka penyediaan oksigen untuk miokard berkurang. ${ }^{5}$ Hipertensi akan mempengaruhi hemoestasis di dalam tubuh. Hipertensi menimbulkan trauma langsung terhadap dinding pembuluh darah arteri koronaria, hal ini menyebabkan angina pektoris, insufiensi koroner dan infark miokard. ${ }^{5}$ Curah jantung low output juga dapat menurunkan suplai oksigen pada sirkulasi sistemik. Hal ini juga akan berujung pada IMA. Penelitian ini bertujuan untuk melakukan evaluasi pada faktor risiko hipertensi terhadap kaitannya dengan kejadian kardiovaskuler mayor di RSUP Sanglah Denpasar selama periode 2018.

\section{BAHAN DAN METODE}

Penelitian merupakan penelitian rancangan kohort retrospektif dengan dengan mengambil data sekunder (rekam medis) untuk membuktikan hipertensi sebagai prediktor kejadian kardiovaskular mayor pada penderita IMA. Data Sekunder Penderita IMA dikelompokkan menjadi 2 kelompok yaitu kelompok penderita IMA dengan hipertensi dan kelompok penderita IMA dengan normotensi. Luaran (outcome) yang dimonitor adalah kejadian kardiovaskular mayor yang meliputi kematian dengan penyebab kardiovaskular, syok kardiogenik, gagal jantung dan aritmia lethal. Penelitian ini menghasilkan Hazard Ratio (HR) 
dan kurva survival dari faktor prognostik tersebut terhadap kejadian kardiovaskular mayor.

Pengambilan sampel adalah secara consecutive sampling dari populasi penelitian yaitu penderita IMA (STEMI dan NSTEMI) yang memenuhi kriteria inklusi dan tidak memenuhi kriteria eksklusi berjumlah 70 pasien selama periode Januari sampai September 2018. Data karakteristik pasien seperti jenis kelamin, umur, indeks masa tubuh (IMT), tekanan darah, riwayat hipertensi, riwayat merokok, diabetes melitus, terapi reperfusi, diagnosis, serta hasil laboratorium diperoleh dari catatan medis pasien di RSUP Sanglah. Pencatatan terjadinya kejadian kardiovaskular mayor selama perawatan pasien di rumah sakit yaitu kematian akibat kausa kardiovaskular dan/atau gagal jantung

Tabel 1 Karakteristik Subyek Penelitian (Berdasarkan Tekanan Darah)

\begin{tabular}{|c|c|c|}
\hline \multirow[b]{3}{*}{ Variabel } & \multicolumn{2}{|c|}{ Hipertensi } \\
\hline & Hipertensi & Tidak Hipertensi \\
\hline & $n=39$ & $\mathbf{n}=\mathbf{3 1}$ \\
\hline Rerata umur (tahun), mean + SD & $61,97 \pm 10,21$ & $55,32 \pm 11,31$ \\
\hline \multicolumn{3}{|l|}{ Jenis Kelamin, n (\%) } \\
\hline Laki-laki & $33(84,6 \%)$ & $29(93,5 \%)$ \\
\hline Perempuan & $6(15,4 \%)$ & $2(6,5 \%)$ \\
\hline \multicolumn{3}{|l|}{ Merokok, n (\%) } \\
\hline Ya & $13(35,1 \%)$ & $19(57,6 \%)$ \\
\hline Tidak & $24(64,9 \%)$ & $14(42,4 \%)$ \\
\hline \multicolumn{3}{|l|}{ Dislipidemia, n (\%) } \\
\hline $\mathrm{Ya}$ & $22(59,5 \%)$ & $21(63,6 \%)$ \\
\hline Tidak & $15(40,5 \%)$ & $12(36,4 \%)$ \\
\hline \multicolumn{3}{|l|}{ Diabetes Melitus, n (\%) } \\
\hline Ya & $11(29,7 \%)$ & $3(9,1 \%)$ \\
\hline Tidak & $26(70,3 \%)$ & $30(90,9 \%)$ \\
\hline \multicolumn{3}{|l|}{ Obesitas, $\mathbf{n}(\%)$} \\
\hline $\mathrm{Ya}$ & $3(8,1 \%)$ & $1(3,0 \%)$ \\
\hline Tidak & $34(91,9 \%)$ & $32(93,0 \%)$ \\
\hline \multicolumn{3}{|l|}{ Diagnosis, n (\%) } \\
\hline STEMI & $25(67,6 \%)$ & $28(84,8 \%)$ \\
\hline NSTEMI & $12(32,4 \%)$ & $5(15,2 \%)$ \\
\hline \multicolumn{3}{|l|}{ Terapi Reperfusi, n (\%) } \\
\hline Ya & $26(70,3 \%)$ & $27(81,8 \%)$ \\
\hline Tidak & $11(29,7 \%)$ & $6(18,2 \%)$ \\
\hline Kejadian Kardiovaskul Mayor, n (\%) & $20(54,1 \%)$ & $3(8,6 \%)$ \\
\hline Kematian Kardiovaskuler & $2(5,4 \%)$ & $0(0,0 \%)$ \\
\hline Syok Kardiogenik & $3(8,1 \%)$ & $0(0,0 \%)$ \\
\hline Gagal Jantung & $14(37,8 \%)$ & $2(12,6 \%)$ \\
\hline Aritmia Lethal & $1(2,7 \%)$ & $1(3,0 \%)$ \\
\hline
\end{tabular}

dan/atau syok kardiogenik dan atau aritmia lethal juga dilakukan.

Data didapatkan dengan mengambil data rekam medis periode 1 Januari 2018 sampai dengan 31 September 2018 yang bertempat di RSUP Sanglah, Denpasar. Data kemudian dianalisis dengan bantuan software IBM SPSS Statistics 23 . Uji chi-square test dan perhitungan hazard ratio digunakan untuk mengetahui peranan hipertensi dalam terjadinya KKM, kemudian dilakukan analisis kurva prognostik (Kaplan Meier curve). Seluruh hasil dianggap bermakna apabila nilai $\mathrm{p}<0,05$.

\section{HASIL}

Karakteristik subjek penelitian dikelompokkan menjadi dua yaitu berdasarkan hipertensi dan tidak hipertensi yang dapat dilihat pada tabel 1 . Untuk mengetahui pengaruh hipertensi sebagai prediktor KKM pada pasien IMA, maka dilakukan analisis bivariat. Metode analisis yang digunakan adalah metode estimasi survival dari Kaplan-Meier yang disajikan dalam bentuk grafik estimasi KaplanMeier. Selama penelitian didapatkan sebesar 22 pasien dari 70 pasien IMA yang mengalami kejadian kardiovaskular mayor. Sebanyak 19 pasien diantaranya memiliki hipertensi, sedangkan 3 pasien tidak hipertensi. Gambaran estimasi survival Kaplan Meier terjadinya kejadian kardiovaskular mayor berdasarkan kategori Hipetensi ditunjukkan pada gambar 1.

Survival rate pasien dengan hipertensi didapatkan 5,37 hari $(95 \% \mathrm{CI}=4,787-5,958)$, sedangkan survival rate pasien dengan tidak hipertensi adalah 6,603 hari $(95 \% \mathrm{CI}=6,154-7,051)$. Setelah dilakukan Uji Log Rank, ditemukan bahwa survival rate antara pasien dengan hipetensi dengan tidak hipertensi berbeda secara bermakna dengan nilai $\mathrm{p}=0,002$.

Pengaruh independen hipertensi terhadap KKM pada pasien IMA dilihat dengan nilai hazard ratio (HR) yaitu sebesar 5,026 (95\% CI 1,32-19,20), dan ditunjukkan pada tabel 2. Risiko KKM pada pasien IMA jika ditemukan dengan hipertensi adalah 5 kali lebih tinggi dibandingkan dengan pasien tidak hipertensi. Perbedaan risiko tersebut bermakna secara statistik dengan $\mathrm{p}=0,018$ Nilai HR ini masih bersifat kasar dan belum mengontrol variabel lain yang dianggap sebagai perancu.

Analisis multivariat yang digunakan untuk mengetahui pengaruh Hipertensi terhadap kejadian kardiovaskular mayor secara independen adalah Cox Regression. Variabel yang dimasukkan dalam uji multivariat adalah variabel kendali yang menunjukkan nilai $\mathrm{p}<0,25$ dan variabel yang penting secara teoritis, yaitu variabel jenis kelamin, merokok, diabetes melitus, dislipidemia, dan 
Tabel 2 Analisis Bivariat dan Hazard Ratio (HR) Hipertensi Terhadap Kejadian Kardiovaskular Mayor Pada IMA

\begin{tabular}{lccccc}
\hline & \multicolumn{3}{c}{ KKM } & & \\
Variabel & Ya & Tidak & HR & IK 95\% & $\boldsymbol{P}$ \\
\cline { 2 - 3 } Tekanan Darah & & & & \\
$\quad$ Tinggi & $19(27,1 \%)$ & $20(28,6 \%)$ & 5,026 & $1,32-19,20$ & 0,018 \\
Tidak Tinggi & $3(4,3 \%)$ & $28(40,0 \%)$ & & & \\
\hline
\end{tabular}

Tabel 3 Hasil Analisis Cox Regression Hipertensi Sebagai Prediktor Kejadian Kardiovaskular Mayor pada Pasien IMA

\begin{tabular}{lccc}
\hline Variabel & Exp (B) & $\mathbf{9 5 \% ~ C l}$ & P-value \\
\hline Hipertensi & 5,03 & $1,32-19,20$ & 0,018 \\
Jenis kelamin & 0,80 & $0,24-2,69$ & 0,72 \\
Terapi reperfusi & 0,96 & $0,34-2,77$ & 0,95 \\
Diagnosis & 0,68 & $0,28-1,70$ & 0,41 \\
Obesitas & 4,01 & $0,41-39,33$ & 0,23 \\
Merokok & 0,85 & $0,31-2,33$ & 0,76 \\
Diabetes Melitus & 1,10 & $0,37-3,26$ & 0,861 \\
Dislipidemia & 1,419 & $0,50-3,99$ & 0,508 \\
\hline
\end{tabular}

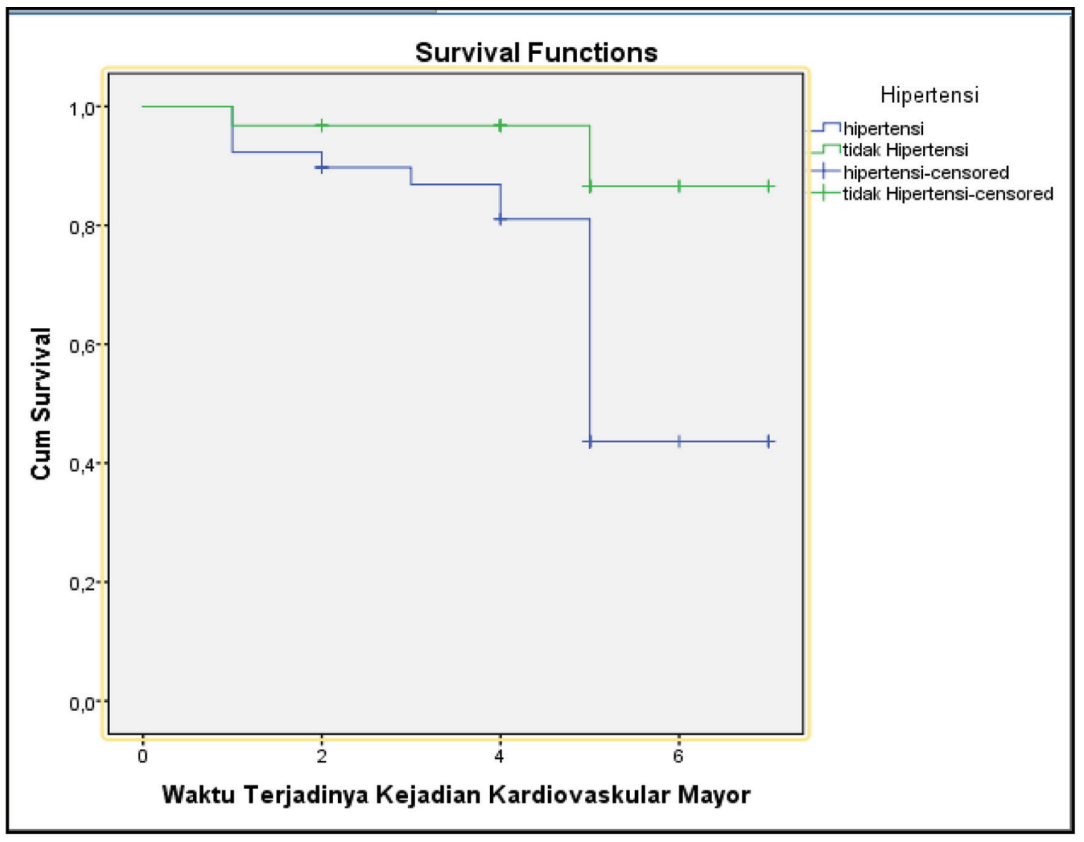

Gambar 1 Kurva Estimasi Survival Kaplan Meier Terjadinya Kejadian Kardiovaskular Mayor Pada IMA Berdasarkan Hipertansi

terapi reperfusi. Analisis multivariat menunjukkan bahwa Hipertensi terbukti sebagai prediktor independen terjadinya kejadian kardiovaskular mayor pada pasien IMA dengan nilai HR sebesar 5,026 dan nilai $p=0,018$ (Tabel 3). Hal ini berarti bahwa risiko kejadian kardiovaskular mayor pada pasien IMA dengan hipertensi setelah mengontrol faktor perancu adalah 5 kali lipat dibandingkan pasien dengan hipertensi

\section{PEMBAHASAN}

Infark miokard akut saat ini masih menjadi penyebab kematian dan kesakitan yang utama di negara berkembang bahkan di negara maju. Penyebab dari kematian dan kesakitan tersebut disebabkan oleh komplikasi Infark Miokard kaut yang dapat berupa komplikasi mekanik, iskemik dan aritmia.

Kejadian kardiovaskular mayor merupakan komplikasi IMA yang berbahaya dan berhubungan dengan survival pasien, terdiri dari kematian kardiovaskular, syok kardiogenik, gagal jantung, dan aritmia lethal. Sistem stratifikasi risiko pada pasien IMA yang cepat dan akurat sangat diperlukan di dalam penanganan pasien IMA sehingga penatalaksanaannya dapat dilakukan secara agresif.

Infark Miokard Akut sebagian besar terjadi disebabkan proses terosklerosis yang berhubungan dengan trombosis pada arteri koroner yang menyebabkan penyediaan oksigen untuk miokard berkurang. ${ }^{5}$ Dengan adanya peningkatan atau penurunan tekanan darah akan mempengaruhi hemoestasis di dalam tubuh yang akan memperparah kondisi pembuluh darah. Selain itu ipertensi menimbulkan trauma langsung terhadap dinding pembuluh darah arteri koronaria yang akan berkembang menjadi angina pektoris, insufiensi koroner dan infark miokard. ${ }^{5}$

Hipertensi didefinisikan penderita dengan tekanan darah sistolik $\geq 140 \mathrm{mmHg}$, dan/atau tekanan darah diastolik $\geq 90 \mathrm{mmHg}$ yang diperiksa pada saat masuk rumah sakit menggunakan alat sphygmomanometer air raksa, berdasarkan klasifikasi JNC VII (Seventh Joint National Committee Clasification) atau penderita dengan riwayat HT dan sedang mengkonsumsi obat antihipertensi. Riwayat HT dan konsumsi obat antihipertensi dapat diketahui berdasarkan anamnesis dan rekam medis pasien. ${ }^{6}$

Peneliti melakukan penelitian kohort retrospektif yang bertempat di RSUP Sanglah Denpasar dengan mengambil data sekunder periode 1 januari 2018 - 30 September 2018. Temuan yang penting dari penelitian ini adalah Hipertensi sebagai prediktor KKM pada IMA. Temuan ini dapat digunakan untuk stratifikasi risiko pada penderita IMA.

Penelitian ini melibatkan 70 sampel yang diambil dengan cara consecutive sampling, terdiri dari 62 orang laki-laki dan 8 orang wanita. Pada penelitian ini, diperoleh bahwa tidak terdapat perbedaan yang bermakna dalam karakteristik dasar pasien bila dikelompokkan berdasarkan hipertensi, kecuali dalam hal prevalensi DM.

Sampel dengan jenis kelamin laki-laki lebih banyak didapatkan pada kelompok hipertensi, yaitu sebanyak $33(47,1 \%)$ laki-laki dan pada tidak hipertensi terdapat 29 orang $(41,4 \%)$ laki-laki. 
Perbedaan ini tidak bermakna secara statistik $(\mathrm{p}=$ 0,243 ). Menurut sejumlah literatur, risiko aterosklerosis koroner lebih besar pada lakilaki daripada perempuan. Perempuan relatif lebih kebal terhadap penyakit ini sampai usia setelah menopause, dan kemudian menjadi sama rentannya seperti pada laki-laki. ${ }^{7}$ Pada penelitian yang dilakukan oleh Dewi dkk, disebutkan bahwa laki-laki memiliki risiko yang lebih tinggi dari pada perempuan untuk terjadinya infark miokard akut, karena pada lakilaki tidak mempunyai efek protektif antiaterogenik yang dipengaruhi oleh hormon esterogen seperti perempuan. Hormon esterogen meningkatkan kadar HDL sehingga menekan kadar LDL dalam darah. ${ }^{8}$

Penelitian ini menunjukkan rerata umur pasien IMA dengan hipertensi dengan tidak hipertensi memiliki perbedaan siginikan ( $61,97 \pm 10,21$ tahun vs $55,32 \pm 11,31$ tahun dengan $p=0,12$ ). Hal ini hampir sama dengan penelitian Reinstadler $\mathrm{dkk}^{18}$ yang meneliti tentang hubungan Hipertensi dengan kejadian mortalitas di rumah sakit pada pasien STEMI, didapatkan rerata umur hipertensi adalah 66 tahun dan pada tidak hipertesni adalah 54 tahun dan secara statistik bermakna dengan nila $\mathrm{p}<0,001$. Hal sama dengan studi oleh Kang $\mathrm{dkk}^{9}$ yang meneliti Hipertensi sebagai prediktor kematian pasien STEMI menemukan $66.8 \pm 11.9 \mathrm{yr}$ vs. $62.1 \pm 13.4 \mathrm{yr}$, dan berbeda signifikan $\mathrm{P}<0.001$. Hubungan antara hipertensi dan semakin bertambahnya umur, Arteri menjadi membesar dan. ${ }^{10}$ Arteri kaku yang mengalami penurunan kapasitansi dan terbatasnya rekoil sehingga tidak dapat mengakomodasi perubahan yang terjadi selama siklus jantung. Selanjutnya, selama sistole pembuluh arteri arteriosklerotik menunjukkan ekspansi terbatas dan gagal menyangga efektif tekanan yang dihasilkan oleh jantung yang menyebabkan peningkatan tekanan darah sistolik (SBP). ${ }^{11}$

Pada penelitian ini ditunjukkan bahwa terdapat lebih banyak pasien IMA yang menderita DM. Pada pasien DM terjadi peningkatan morbiditas dan mortalitas akibat penyakit jantung iskemik, seperti yang telah diungkapkan dalam berbagai studi epidemiologis, termasuk studi Framingham. Dalam sebuah penelitian multisenter observasional prospektif, DM dikenal sebagai prediktor independen yang signifikan terhadap terjadinya mortalitas jantung, kejadian kardiovaskular mayor, kejadian infark miokard akut berulang, dan kejadian rawat inap untuk CHF selama follow-up jangka panjang pada pasien infark miokard akut. ${ }^{12}$ Hal tersebut disebabkan karena pada pasien DM biasanya terjadi proses atherosklerosis yang lebih melalui mekanisme putatif seperti mekanisme stres oksidatif dan glikasi protein pada pembuuh darah. ${ }^{13}$ Berdasarkan penelitian yang dilakukan oleh $\mathrm{Hsu}$ dkk, didapatkan bahwa pasien STEMI yang juga menderita DM memiliki luaran yang lebih buruk selama perawatan di rumah sakit, dibandingkan dengan pasien yang tidak menderita DM. Hal tersebut disebabkan karena adanya peningkatan insiden gagal jantung, reinfark, perluasan area infark, dan iskemia yang rekuren. ${ }^{14}$

Pada penelitian ini menunjukan bahwa hipertensi memiliki hazard ratio sebesar 5,026 (HR $=5,026,95 \%$ CI $1,32-19,20$, nilai $\mathrm{p}=0,018)$, artinya pada pasien IMA yang memiliki hipertensi memiliki risiko terhadap KKM 5 kali lipat lebih besar dibandingkan dengan kelompok pasien dengan tidak hipertensi. Penelitian ini menunjukkan bahwa hipertensi terbukti sebagai prediktor terjadinya KKM pada pasien IMA.

Untuk membuktikan hipertensi sebagai prediktor independen terjadinya KKM, maka dilakukan analisis multivariat menggunakan Cox Regression. Variabel yang dimasukkan dalam uji multivariat adalah variabel kendali yang menunjukkan nilai $\mathrm{p}<0,25$ dan variabel yang secara teoritis penting. Variabel dengan nilai $\mathrm{p}<0,25$ adalah jenis kelamin. Variabel diagnosis, terapi reperfusi dan onset memiliki nilai $p>0,25$ namun secara teoritis dianggap penting, sehingga dimasukkan ke dalam analisis multivariat.

Penyakit jantung koroner akibat Aterosklerosis masih merupakan penyebab terbanyak dari angka mortalitas dan morbiditas pada negara berkembang. Inflamasi memiliki peran yang sangat penting dalam pembentukan dan komplikasi dari aterosklerosis. ${ }^{15}$ Hipertensi merupakan faktor yang langsung berpengaruh dalam perkembangan aterosklerosis dengan melalui stress mekanis. Hipertensi dapat meningkatkan aterosklerosis melalui hiperaktif simpatik sehingga memperburuk resistensi insulin, melalui vasokonstriksi simpatik pada ekstraksi glukosa pada otot rangka, resistensi insulin yang dimediasi beta adrenoreseptor, dan fragmentasi vaskular karena penutupan pembuluh darah yang lebih kecil karena hipertrofi vaskular. Hipertensi simpatis sendiri juga berkontribusi pada risiko kematian mendadak yang lebih tinggi, kejang koroner, dan trombosis koroner. ${ }^{16}$

Salah satu faktor utama yang menyebabkan perkembangan aterosklerosis pada pembuluh darah pasien hipertensi adalah stres mekanis. Ini terdiri dari kekuatan tiga dimensi: shear stress, transmural stress, wall stress. Shear stress telah terbukti bertanggung jawab atas aktivasi angiotensin II pada pasien hipertensi karena sel endotel kultur yang terpapar pada shear stress memiliki ekspresi gen ACE yang lebih tinggi. Transmural stress menghasilkan "bet effect of pressure" pada sel endotel in vitro (kekurangan kekuatan lainnya) dan sel halus vaskular, sehingga meningkatkan produksi dan 
pertumbuhan sel halus baru. Terakhir, wall stress, pada sel otot polos pembuluh darah kultur, dapat meningkatkan pelepasan faktor yang merangsang sintesis DNA dan protein; Membentang sel-sel halus pada gilirannya menginduksi aktivitas ACE dan pertumbuhan sel, akhirnya menyebabkan hipertrofi sel otot. Hipertrofi ventrikel kiri untuk meningkatkan kekuatan pompa. ${ }^{5}$ Kondisi hipertrofi mengakibatkan kebutuhan oksigen miokard meningkat. Bila proses asteroklorosis terjadi, maka penyediaan oksigen untuk miokard berkurang. ${ }^{5}$ Peningkatan atau penurunan tekanan darah akan mempengaruhi hemoestasis di dalam tubuh. Hipertensi menimbulkan trauma langsung terhadap dinding pembuluh darah arteri koronaria, hal ini menyebabkan angina pektoris, insufiensi koroner dan infark miokard. ${ }^{17}$

Studi terbaru juga membahas hipertensi berkontribusi dalam risiko terjadinya Kejadian Kardiovaskular Mayor pada IMA. Reinstadler dkk. tahun 2016 melaporkan bahwa Hipertensi merupakan prediktor independen dari meningkatnya risiko kejadian kardiovaskular mayor dan risiko mortalitas pada pasien STEMI. Pada penelitiannya Reinstadler dkk. mengamati 792 pasien STEMI dan diamati luaran yang terjadi dalam 12 bulan pasca serangan. Pada pasien pasca STEMI dengan follow up selama 12 bulan, 53 pasien (7\%) mengalami MACE. Dari jumlah tersebut 22 (3\%) meninggal. Pasien dengan hipertensi beresiko tinggi untuk MACE dengan hazard ratio 2,70 dan mortalitas dengah hazard ratio 4,83 dibandingkan dengan pasien tanpa hipertensi. ${ }^{18,19}$

Studi dari Kang dkk. tahun 2009 menyimpulkan bahwa hipertensi merupakan prediktor kematian kejadian IMA pada di Korea. Sebanyak 8.568 pasien dengan MI akut terdaftar di KASHMIR dari November 2005 hingga Desember 2006, dan 7.784 pasien (5.430 pria dan 2.354 wanita diamati bulan ke 1, 6, dan 12. Sepanjang pengamatan didapatkan angka mortalitas dan morbiditas saat perawatan di rumah sakit dan 1 tahun pasca serangan tidak memiliki perbedaan signifikan, namun angka kematian kardiovaskular ditemukan lebih tinggi pada kelompok hipertensi dibandingkan dengan tidak hipertensi dengan hazard ratio 1,33., ${ }^{917}$ Parodi dkk. tahun 2006 juga menemukan Hipertensi sebagai prediktor kematian di rumah sakit pada pasien IMA. Sebanyak 953 pasien (324 hipertensi) dengan IMA menjalani 5 tahun follow-up. Pada penelitian ini hipertensi ditemukan menjadi prediktor gagal jantung (hazard ratio, 2,23). ${ }^{15,20}$

Setelah dikontrol dengan variabel perancu pada analisis multivariat, hipertensi terbukti merupakan prediktor independen terhadap KKM dengan nilai HR 5,02. Artinya hipertensi merupakan prediktor independen untuk terjadinya kejadian kardiovaskular mayor dengan risiko 5 kali lipat lebih besar dibandingkan tidak hipertensi.

Dari studi tersebut dapat dilihat bahwa nilai prognosis Hipertensi memiliki nilai HR/OR/RR tertinggi sebesar 5,02. Merujuk bahwa nilai risiko diatas 2,0 merupakan nilai risiko yang dianggap bermakna, maka hipertensi merupakan petanda prognostik yang baik dalam memprediksi terjadinya kejadian kardiovaskular pada pasien pasca IMA. Sebagai petanda prognostik yang baik, maka hipertensi dapat digunakan sebagai modalitas pencegahan sekunder pada pasien IMA di RSUP Sanglah.

\section{SIMPULAN}

Studi kohort retrospektif telah dilakukan untuk membuktikan hipertensi sebagai prediktor kejadian kardiovaskular mayor pada pasien infark miokard akut di RSUP Sanglah. Berdasarkan hasil penelitian maka dapat disimpulkan bahwa: hipertensi merupakan prediktor kejadian kardiovaskuler mayor pada pasien infark miokard akut saat perawatan di rumah sakit.

\section{SARAN}

1. Berdasarkan hasil penelitian, Riwayat hipertensi dapat digunakan sebagai salah satu modalitas stratifikasi risiko pada pasien infark miokard akut yang penting, sederhana dan mudah.

2. Dapat dilakukan penelitian lanjutan dengan menggunakan data primer melalui follow up secara langsung pada pasien, secara multicentre dan menggunakan sampel yang lebih besar, sehingga dapat lebih digeneralisasi terhadap populasi pasien infark miokard akut dengan berdasarkan pada profil lipid pasien

\section{KONFLIK KEPENTINGAN}

Penulis menyatakan tidak terdapat konflik kepentingan terkait publikasi dari artikel ini.

\section{PENDANAAN}

Penelitian ini tidak mendapatkan bantuan dana dari pemerintah aatupun lembaga swasta lainnya

\section{ETIKA DALAM PENELITIAN}

Penelitian ini telah disetujui oleh Komite Etik Fakultas Kedokteran, Universitas Udayana/RSUP Sanglah Denpasar dengan nomer referensi 1794/ UN14.2.2.VII.14/LP/2018 


\section{DAFTAR PUSTAKA}

1. Benjamin E, Emelia J, Michael JB, Stephanie EC. Heart Disease and Stroke Statistics-2017 Update. A Report From the American Heart Association. Circu;lation. 2017;135:e146-e603.

2. Mullasari AS, Balaji P, Khando T. Managing complications in acute myocardial infarction. J Assoc Physicians India.. 2011;59(Suppl1):43-48.

3. Gerber Y, Susan AW, Maurice ES, Cecilia B, Alanna M. Chamberlain SM, Ruoxiang J, Shannon MD, Véronique LR. Mortality Associated With Heart Failure After Myocardial Infarction A Contemporary Community Perspective. Circ Heart F. 2016;9(1):e002460.

4. de Araújo GP, Ferreira J, Aguiar C, Seabra GR. TIMI, PURSUIT, and GRACE risk scores: sustained prognostic value and interaction with revascularization in NSTE ACS. European Heart Journal. 2005;26(9):865-872.

5. Price SA, Wilson LM, editor. Patofisiologi: konsepklinis prosesproses penyakit Edisi ke-6, Volume 1. Jakarta: Penerbit Buku Kedokteran EGC; 2006.

6. Chobanian AV, Bakris GL, Black HR, Cushman WC, Green LA, Izzo JL Jr, et al. Seventh report of the Joint National Committee on Prevention, Detection, Evaluation, and Treatment of High Blood Pressure. Hypertension. 2003;42(6):1206-52.

7. Brown CT, Penyakit aterosklerotik koroner. Dalam: terjemahan Hartanto H. Price SA, Wilson LM, editor. Patofisiologi, Konsep Klinis Proses-Proses Penyakit. Edisi ke-6. Jakarta: EGC; 2006.

8. Dewi MR, Haryati DS, Sumardino. Faktor -Faktor Dominan Sindrom Metabolik Yang Berhubungan Dengan Kejadian Akut Miokard Infark (AMI) di ruang Intensive Cardiovasculer Care Unit (ICVCU) RSUD Dr. Moewardi Tahun 2014. Jurnal KesMaDaSka. 2014;67:105-116.

9. Kang DG, Myung HJ, Yongkeun A, et al. Clinical Effects of Hypertension on the Mortality of Patients with Acute Myocardial Infarction. J Korean Med Sci. 2009;24:800-6.

10. O'Rourke MF, Hashimoto J. Mechanical factors in arterial aging: a clinical perspective. J Am Coll Cardiol. 2007;50:1-13.

11. Millar JA, Lever AF. Implications of pulse pressure as a predictor of cardiac risk in patients with hypertension. Hypertension. 2000;36:907-911.

12. Park HW, et al. Long-term Prognosis and Clinical Characteristics of Patients with Newly Diagnosed Diabetes Mellitus Detected after First Acute Myocardial Infarction: from KAMIR-NIH Registry. Korean Circulation Journal. 2018;48(2):134-147.
13. Lee MG, Myung HJ, Ki HL, et al. Prognostic Impact of Diabetes Mellitus and Hypertension for Mid-term Outcomeof patient with Acute Myocardial Infarction who Underwent Percutaneus Coronary Intervention. J Cardiol. 2012;60:257-263.

14. Huang Y, Cai X, Li Y, et al. 2014. Prehypertension and the risk of stroke: a meta-analysis. Neurology. 2014;82(13):1153-61.

15. Parodi,Guido, Nazario Carrabba, Giovanni M., et al. Heart Failure and Left Ventricular Remodeling After Reperfused Acute Myocardial Infarction in Patients With Hypertension. Hypertension. 2006;47:257-263.

16. Julius $S$. Sympathetic hyperactivity and coronary risk in hypertension. Hypertension. 1993;21(6):886-893.

17. Djohan T. Penyakit jantung koroner dan hipertensi [Internet]. Sumatera Utara: e-USU Repository; 2006 [Diakses 10 Agustus 2018]. Tersedia di: http://repository. usu.ac.id/bitstream/handle/123456789/705/08E00124.pdf; jsessionid $=8$ FE08473AD19EB9F35D3086733F351EA? sequence $=1$.

18. Reinstadler SJ, Thomas S, Charlotte E, et al. Antecedent hypertension and myocardial injury in patients with reperfused STelevation myocardial infarction. Journal of Cardiovascular Magnetic Resonance. 2016;18(1):1-8.

19. Pertiwi GAR, Aryawangsa AAN, Prabawa IPY, Manuaba IBAP, Bhargah A, Budiana IPG. Factor associated with visit-to-visit variability of blood pressure in hypertensive patients at primary health care service, Tabanan, Bali, Indonesia. FMCH. 2018;6(4):191-199. DOI: https://doi. org/10.15212/FMCH.2018.0124.

20. Handoyo V, Pertiwi GAR, Prabawa IPY, Manuaba IBAP, Bhargah A, Budiana IPG. Management of ST-elevation myocardial infarction in the setting of anterior epistaxis: focused on antiplatelet and antithrombotic therapies. International Journal of Medical Case Report. 2019;12:3338. DOI: http://dx.doi.org/10.2147/IMCRJ.S189370.

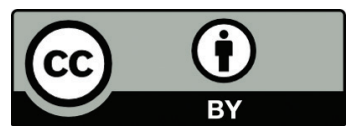

This work is licensed under a Creative Commons Attribution 